Author(s) : Anne Eskild

Article title : Induced abortion: a means of postponing childbirth? Changes in maternal age at induced abortion and child birth in Norway during 1971-2007

Article no : 526183

Dear Author,

Please check these proofs carefully. It is the responsibility of the corresponding author to check against the original manuscript and approve or amend these proofs. A second proof is not normally provided. Informa Healthcare cannot be held responsible for uncorrected errors, even if introduced during the composition process. The journal reserves the right to charge for excessive author alterations, or for changes requested after the proofing stage has concluded.

The following queries have arisen during the editing of your manuscript and are marked in the margins of the proofs. Unless advised otherwise, submit all corrections using the CATS online correction form. Once you have added all your corrections, please ensure you press the "Submit All Corrections" button.

AQ1: We have inserted a running head. Please approve or provide an alternative running head.

AQ2: Please check that the author names and affiliations have been set correctly.

AQ3: Please confirm I have been deleted parenthesis here.

AQ4: A declaration of interest statement reporting no conflict of interest has been inserted. Please confirm whether the statement is accurate. 


\section{healthcare}

\section{ACTA OBSTETRICIA ET GYNECOLOGICA SCANDINAVICA color policy}

Any figure submitted as a color original will appear in color in the journal's online edition free of charge. Color reproduction in the print edition is available if the authors, or their funding body, bear the associated costs. The charge for the first color page is USD $\$ 1000$, second and third pages are charged at USD $\$ 500$ each. For four or more pages please contact us for a quote. All orders or inquiries must be made on or before the proof due date.

\section{Article details}

$\square$ I wish to pay for color in print. The manuscript (CATS) ID of my article is: (six digit number)

Article title:

Author name:

Please detail the figure/part numbers for color printing:

\begin{tabular}{|l|c|c|c|c|}
\hline Number of color pages & $\mathbf{1}$ & $\mathbf{2}$ & $\mathbf{3}$ & $\mathbf{4 +}$ \\
\hline Total price & $\$ 1000$ & $\$ 1500$ & $\$ 2000$ & Contact us for a quotation \\
\hline
\end{tabular}

Number of color pages: Total color costs: (see table above)

\section{Payment options}

An invoice or credit card payment will be raised when the issue containing your paper is sent to press.

\section{EITHER pay by credit card}

Credit Card $\square$ Please charge my AMEXNISA/MasterCard (delete as appropriate)

Card No
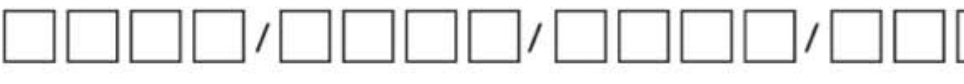

Exp.date

$\mathrm{CVV}$ number (last 3 or 4 digits on reverse of card):

Name on credit card:

Address where registered:

Signature:

Date:

OR invoice to:

Signed:

Date:

Print name:

\section{Scan and email the completed form to journal-production@informa.com or fax to $+\mathbf{4 4} \mathbf{2 0 7 0 1 7 7 8 3 1}$}

\section{NOTES}

If requested, and if possible, at proof stage we can group images from various pages onto one page to reduce color costs. Please give guidance in your proof corrections if this is the case. Color costs are by PAGE not per image, and size has no relevance.

RightsLink author reprints are manufactured separately from the printed journal and are printed in black and white by default. Author reprints ordered prior to your color in print order being processed will be printed in black and white. If you wish to order color reprints of your article, please wait until your color in print order is processed then access the RightsLink reprint ordering link where you will be able to select an option for color.

If you do not wish to pay for color printing, please ensure that all figures/images and legends are suitably amended to be read, and understood, in black and white. It is the author's responsibility to provide satisfactory alternatives at proof stage. Please access the instructions for authors for further guidance on figure quality at: http://informahealthcare.com/obs 
Acta Obstetricia et Gynecologica. 2010; 00: 000-000

informa

healthcare

\title{
Induced abortion: a means of postponing childbirth? Changes in maternal age at induced abortion and child birth in Norway during 1971-2007
} \\ MARIANNE VLIETMAN ${ }^{1}$, AASHI AMBAREEN SARFRAZ ${ }^{1} \&$ ANNE ESKILD $^{1,2}$ \\ ${ }^{1}$ Department of Obstetrics and Gynaecology, Akershus University Hospital and Medical Faculty Division, University of \\ Oslo, 1478 Lørenskog, Norway, and ${ }^{2}$ Department of Mental Heath, Norwegian Institute of Public Health, Box 4404 \\ Nydalen, 0304 Oslo, Norway
}

\begin{abstract}
Objective. The maternal age at child birth is increasing. If induced abortion is an important means of postponing childbirth in a population, it is to be expected that in young women the rate of conceived pregnancies is stable over time, but the induced abortion rate is increasing. We studied birth rates, induced abortion rates and the sum of these rates by maternal age during four decades. Design. Register-based study. Setting and population. All women 15-49 years living in Norway. Methods. We present temporal changes in birth rates and induced abortion rates within age groups during the period 1979-2007. We also estimated the sum rate of births and induced abortions. Data were obtained from national statistics. Main outcome measures. Live births and induced abortions per 1000 women per year. Results. The induced abortion rates have been relatively stable within age groups, except for a decrease in women 15-19 years (from 24.2 in 1979 to 17.0 in 2007) and an increase in women 20-24 years (from 23.2 to 29.5). The birth rates however, have decreased dramatically in women 20-24 years old (from 113.6 to 60.5 ). Hence, the sum rate of births and induced abortions in women 20-24 years old has decreased from 136.8 to 90.0. In women 30 years old or older, the birth rates have increased. Conclusion. The induced abortion rate has been relatively stable in all age groups over time, suggesting a limited influence of induced abortions on the postponement of childbearing.
\end{abstract}

Key words: Birth rate, induced abortion rate, population study, risk factors

\section{Introduction}

Maternal age at delivery is increasing in the Western world (1-3). In Europe, women in Lichtenstein and Spain had the highest mean age at child birth with 31.3 and 30.9 years, respectively, in 2006 (4).

Maternal age at child birth may be determined by socioeconomic factors, sexual behaviors, fertility, use of contraceptives and availability of induced abortions $(1,5)$. Safe contraception is easily accessible (6) and termination of first-trimester pregnancy on the woman's request is legalized and safely performed in health care settings in many European countries (7). To what extent induced abortions at a young age account for the postponement of childbearing? This question is not easily answered since few countries have reliable figures on age specific induced abortion rates.

In 1971, the mean age of Norwegian first time mothers was 22.5 years, while it was 28.1 years in 2007 (8). Among all childbearing women, the mean age was 30.3 years in 2007 (9). Induced abortion on the woman's request before 12 completed pregnancy weeks has been performed legally in Norway since 1979 , and the number of induced abortions per year has been stabile (10). Also, in other Nordic countries, the mean maternal age at child birth has increased, whereas the overall abortion rates have remained relatively unchanged (11).

If induced abortion has been used for the postponement of childbirth, it is to be expected that the

Correspondence: Anne Eskild, Department of Obstetrics and Gynaecology, Akershus University Hospital and University of Oslo, 1478 Lørenskog, Norway. E-mail: anne.eskild@medisin.uio.no 
induced abortion rate has increased in younger women, while the sum of induced abortion and birth rates has remained unchanged. In all women 15-49 years living in Norway, we studied changes in age specific birth rates during 1971-2007 and age specific induced abortion rates during 1979-2007.

\section{Materials and methods}

All women in Norway who were between 15 and 49 years of age during the period 1971-2007 were included in our study.

The number of live births per 1000 women in different age groups was obtained from the Medical Birth Registry of Norway (10), where the rates were calculated on the basis of the age distribution in the population as obtained by the Population Registry of Norway. This registry includes all individuals with legal stay in Norway and the information on child birth is obtained by compulsory notification of births after 16 weeks of gestation to the Population Registry AQ3 and to the Medical Birth Registry of Norway.

The number of induced abortions per 1000 women in each age group was obtained from Statistics Norway (12) and was available from 1979. Induced abortions are performed at hospitals only, and the hospitals report their numbers of induced abortions according to the women's age and county of residence on standardized forms. Such reporting is compulsory by law. In Norway, termination of pregnancy is legally performed on the woman's request up until the end of the 12th week of pregnancy. Thereafter, a legal abortion requires the authorization of a committee composed of two physicians (13). Approximately $4 \%$ of induced abortions are performed after the 12th week of pregnancy (14). Norway's current induced abortion law has remained unchanged since 1979.

We present the number of live births per 1000 women in the age groups 15-19, 20-24, 25-29, 30-34, 35-39, 40-44 and 45-49 years old for every year during the period 1971-2007. The number of induced abortions per 1000 women was not available before 1979 and is therefore presented for the period 1979-2007. We also calculated the sum of births and induced abortions per 1000 women in the different age groups.

\section{Results}

In the population as a whole, the rates of induced abortions and births have been relatively stable during our study period. The abortion rate has been approximately 14 per 1000 women per year and the birth rate has been 55 per 1000 women per year (Figure 1).

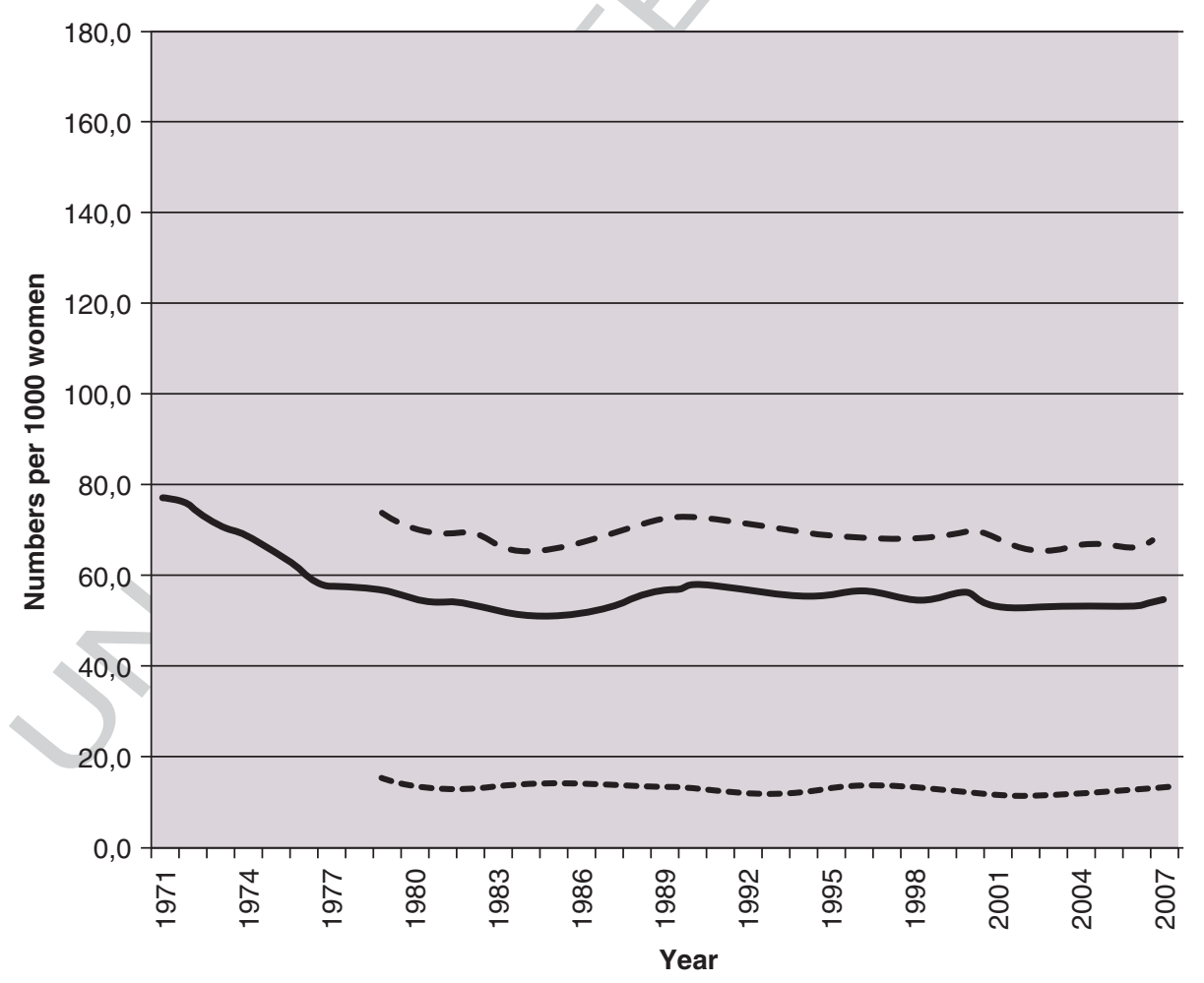

Figure 1. The total number of induced abortions (-1979-2007 and births ( 1000 women in Norway. The sum rate of births and induced abortions is presented as a striped line 
In women between 25 and 40 years old, only little variation in the induced abortion rate was observed (Figure 2, Table 1). In women 20-24 years old, however, the rate increased from 23.2 induced abortions per 1000 women in 1979 to 29.5 per 1000 women in 2007. As a contrast, in 15-19 year old women, the induced abortion rate decreased from 24.2 to 17.0 during the same time period. In 40-44 year old women, the overall induced abortion rate was low, and decreased from 7.4 to 4.2 per 1000 women during the period.

The temporal changes in birth rates revealed striking differences between age groups (Figure 2, Table 1). In 15-19 year old women, the birth rate decreased from 45.7 births per 1000 women in 1971 to 9.1 births per 1000 women in 2007. The absolute decrease in birth rate was even more pronounced in women 20-24 years from 168.7 to 60.5 births per 1000 women. In 1979 the birth rate was 113.6, and it decreased steadily to 58.6 in 2005 . Opposite trends were seen in women 30-39 years, and the birth rates increased from 62.4 to 123.2 in women 30-34 years old, and from 22.2 to 54.1 in 35-39 year old women. In 25-29 year old women, the birth rate pattern was more complex. In the beginning of the period, the birth rate decreased from 151.5 in 1971 to 120.3 in 1983. Thereafter, the birth rate increased and reached a peak in 1990 with 144.0 births per 1000 women, but has been declining since 1990 .

The sum of induced abortion and birth rates decreased in women 20-24 years old from 136.8 per 1000 women in 1979 to 90.0 per 1000 women in 2007. In this age group, terminated pregnancies represent an increasing proportion of all conceived pregnancies from $17 \%$ in 1979 to $32 \%$ in 2007 . Also among the 15-19 year old women, there has been a large decline in the sum of induced abortion and birth rates, but despite a decrease in abortion rates, the proportion of pregnancies that are terminated has increased, from $47 \%$ in 1979 to $65 \%$ in 2007 . An opposite trend was seen among older women. Since the birth rates have increased, and the induced abortion rates have been relatively stable over time, the proportion of conceived pregnancies that are terminated has declined.

\section{Discussion}

There has been a major age shift in birth rates across age in Norway during the period 1971 through 2007, with a marked decrease in women less than 25 years old and an increase in women above 30 years. The induced abortion rates, however, have been relatively stable over time, except for a decrease in women

Maternal age at induced abortion and child birth

15-19 years old and an increase in women $20-24$ years old. The changes in induced abortion rates in women less than 25 years are relatively limited as compared to the almost $70 \%$ decline in birth rates. Hence, increased utility of induced abortion to control fertility cannot explain the large decline in birth rates in women less than 25 years. The most likely explanation for this decline is increased use of contraceptives.

Maternal age at delivery has been increasing throughout Europe (3), but the influence of induced abortion on the postponement of child birth has, to our knowledge, not been studied on a national level and over a long period of time. A study in the United States concluded that the birth rates in young women declined as a result of improved access to induced abortion and contraceptives (15). The women's reproductive pattern later in life was not addressed. In many countries, induced abortion is illegal and thereby not reported or the reporting is insufficient for estimates of age specific rates.

In Norway, notification of births to the Medical Birth Registry and induced abortions to Statistics Norway is compulsory by law, and the standard notification forms have remained essentially unchanged during our study period. It is therefore unlikely that systematic errors in reporting according to period or maternal age have occurred. All births and induced abortions take place in public hospitals, and the hospitals are responsible for the reporting. The hospital stay and the treatment are free of charge. Underreporting due to illegal abortions or home births is therefore unlikely.

Our data did not allow for stratified analyses by the mother's country of birth. During our study period, there has been considerable immigration of women from developing countries to Norway, and every fifth child today has a parent who has immigrated. In the beginning of our study period only few mothers were not born in Norway or another Nordic country. In general, non-Western women have higher fertility than Norwegian women, and they also become first time mothers at a younger age (16). The estimated decline in birth rates in young women born in Norway may, therefore, have been even more pronounced than our results indicate since non-Western women are overrepresented in this age group.

Following the decline in birth rates in 20-24 year old women in the beginning of the 1970s, there was an increase in women above 25 years ten years later. This increase was followed by a decline since 1991 . Thus, postponement of childbearing, also in 25-29 year old women, may explain the increasing birth rates in women older than 30 years. The overall birth rate in Norway has been stable during our study period. Changes in age specific birth rates cannot be 
15-19 years old

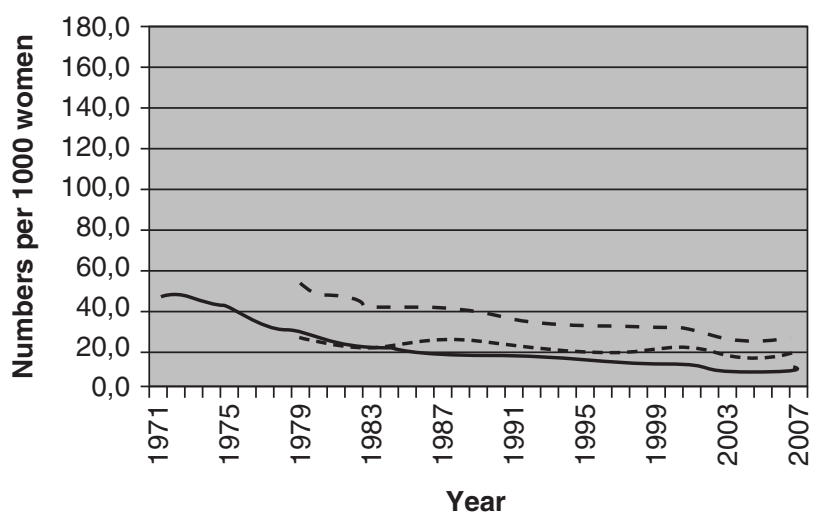

25-29 years old

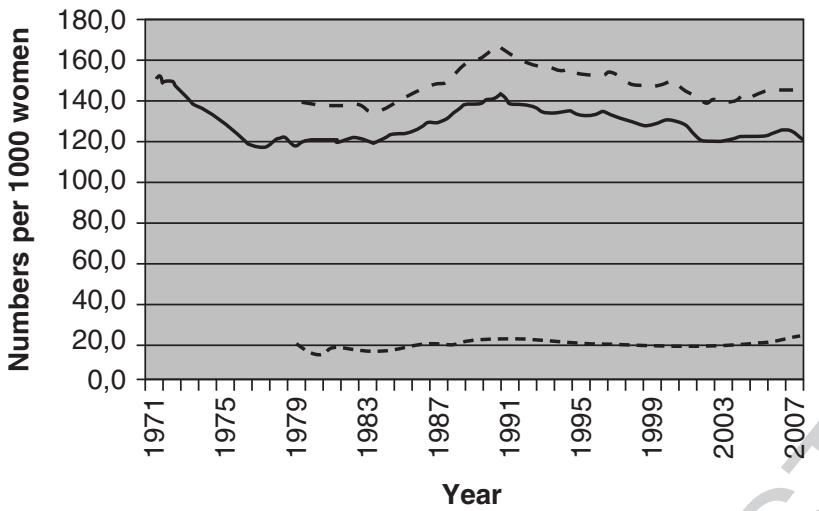

35-39 years old

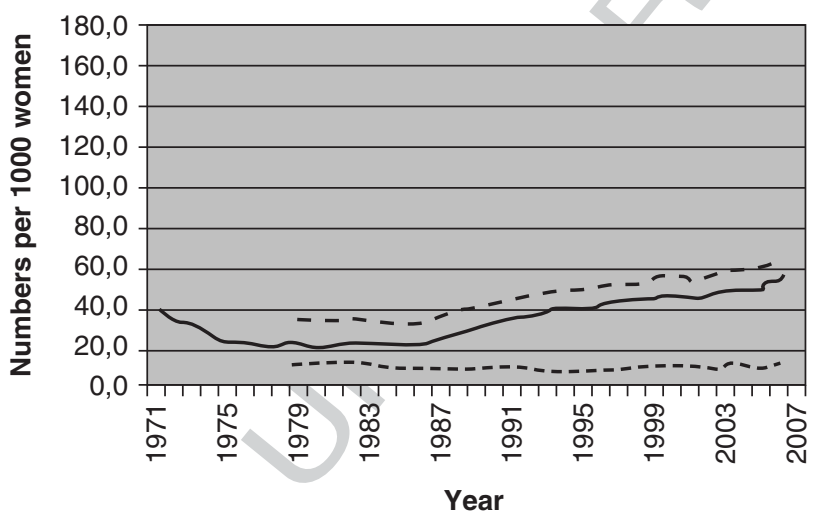

20-24 years old

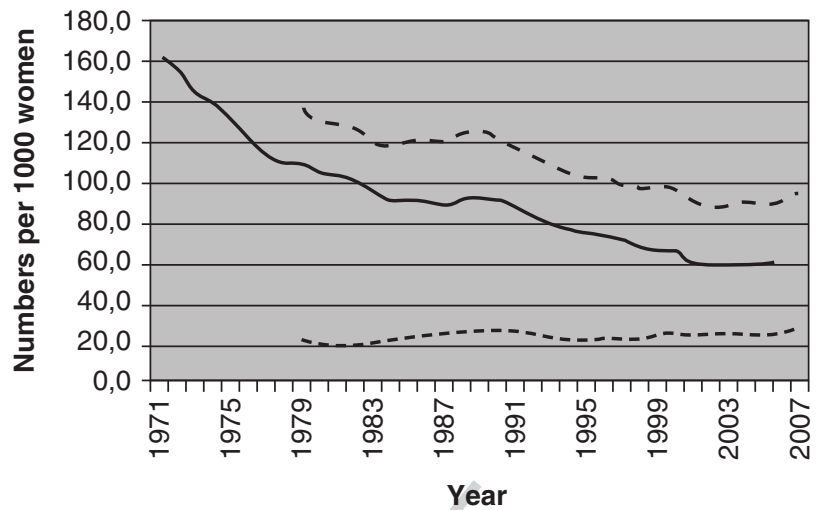

$30-34$ years old

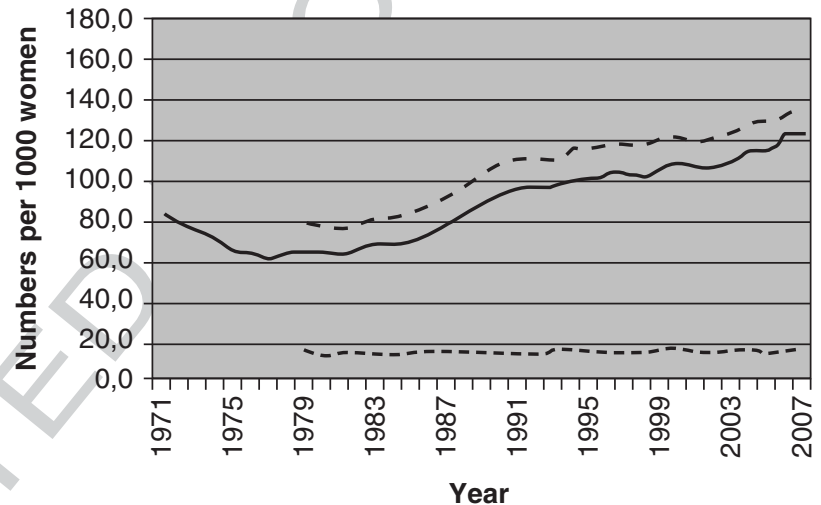

40-44 years old

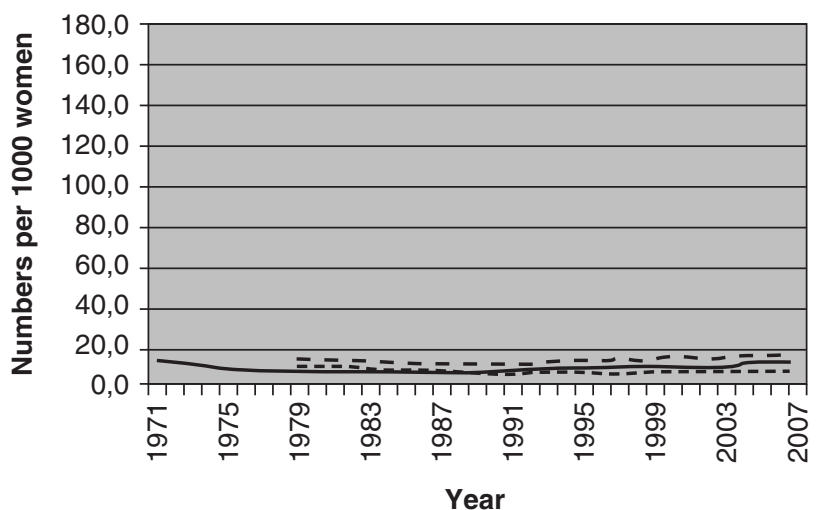

Figure 2. Number of induced abortions (--1-1 - - - during 1979-2007 and births

-) during 1971-2007 per 1000 women in Norway, according to maternal age. The sum rate of births and induced abortions is presented as a striped line (- - - - - - ). 


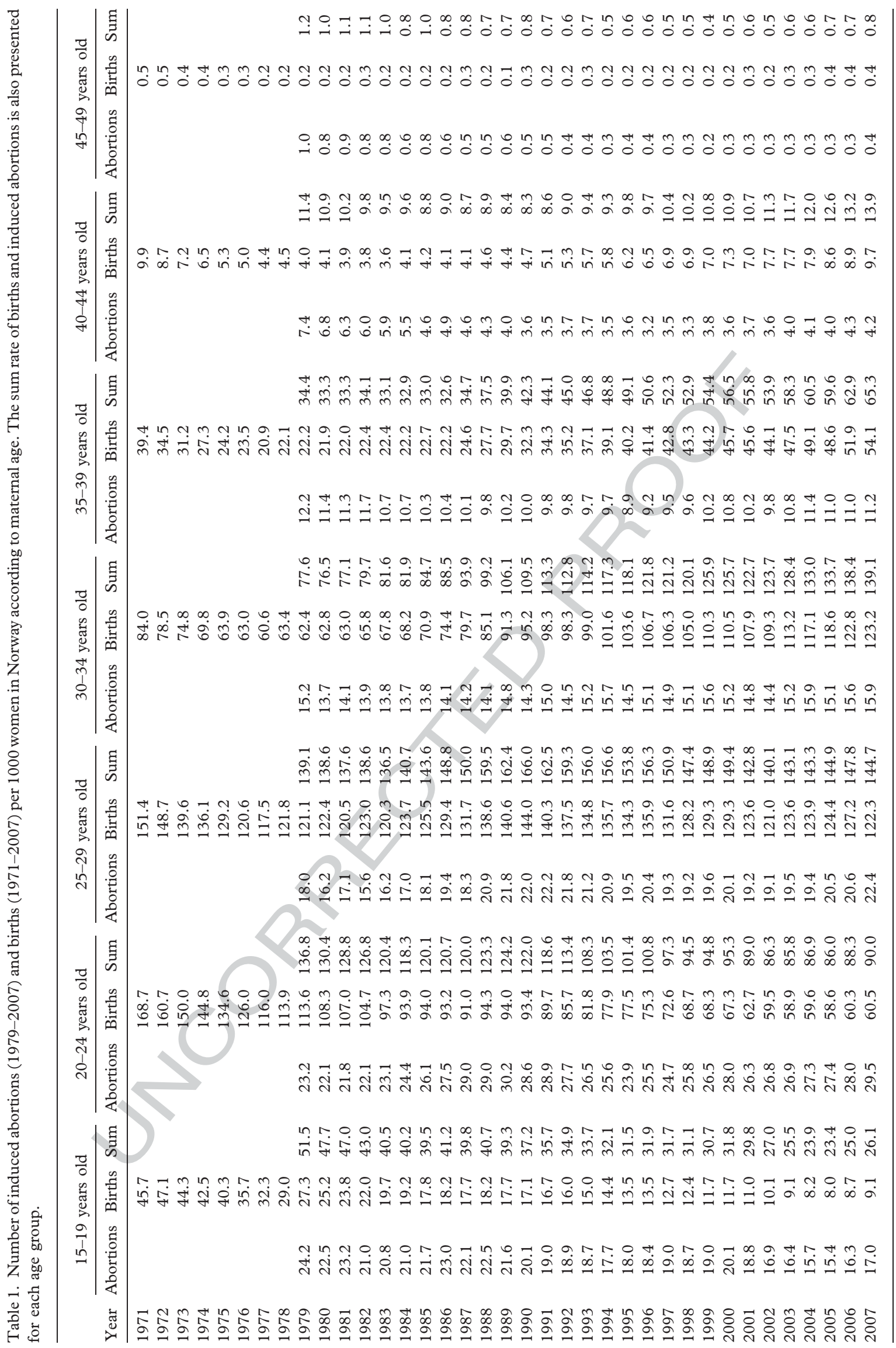


explained by changes in induced abortion rates since the induced abortion rates have been relatively stable across maternal age.

In our population of young women, the rate of conceived pregnancies has decreased dramatically during 40 years. This decline is likely to be explained by an increased use of contraceptives. The birth control pill became generally available to Norwegian women in 1967 (17), and the use has increased from 19,341 defined daily doses in 1967 to about 214,660 defined daily doses in 2007 (18). Information on the age distribution among users is not available (19). During our study period, there have been large scale public health efforts for prevention of unwanted pregnancies and induced abortions, in particular among young women. During the years 2002-2006, the birth control pills were available for women 15-19 years of age free of charge at the pharmacies prescribed by midwifes or public health nurses in addition to doctors (20). In addition, emergency contraceptives have been available without prescription in Norway since 2000 (21). These efforts may have had an impact on induced abortion rates in teenagers (20).

Despite increased utilization of contraceptives and large public efforts to prevent induced abortions, there has been little change in the overall induced abortion rate. The preventive efforts may, however, have influenced the birth rates. The lack of decline in induced abortion rates suggests that a stable proportion of women over time are prone to intercourse without use of contraceptives and to utilize induced abortion for unwanted pregnancy. Risk factors for induced abortion include being under education, being single with no steady partner, no other children, coming from a broken home, little supervision during childhood and adolescence and alcohol abuse among the parents (22-25). The proportion of women with such risk factors may not have declined over time. On the contrary, the proportion of women being under education has increased. Increased length of education is a common explanation for the postponement of childbearing. However, childbearing and rearing may not be easier while being employed than while being a student.

The public maternity welfare program in Norway is generous and includes 10 months of paid parental leave from work now. However, the level of payment during parental leave depends on maternal working force participation and income prior to delivery. Most young women today are either students or tend to have low income, both factors strongly limiting their maternity welfare benefits. The public maternity welfare program, which provides benefits according to income before childbirth, may therefore enhance delayed childbearing since income often increases by age. During the 1990s, the duration of paid maternity leave increased from four to ten months. It may be speculated that the decrease in birth rates in 25-29 year old women since 1991 is attributed to this change since their private economy while nursing an infant would be much improved by postponing childbearing.

Effective contraceptives and access to safely performed induced abortions have improved women's opportunity to make reproductive choices. Delayed age at child bearing may be advantageous, but is also associated with increased risk of infertility, miscarriage, fetal death and other complications in pregnancy.

Our results show marked changes in age specific birth rates in Norway during 1971-2007 from childbearing in the early 20 s to the early 30 s. The induced abortion rates have been relatively stable in all age groups over time suggesting a limited influence of induced abortions on the postponement of childbearing.

Declaration of interest: The authors report no conflicts of interest. The authors alone are responsible for the content and writing of the paper.

\section{AQ4}

\section{References}

1. Eggert J, Sundquist K. Socioeconomic factors, country of birth, and years in Sweden are associated with first birth fertility trends during the 1990s: a national cohort study. Scand J Public Health. 2006;34;504-14.

2. Martin JA, Hamilton BE, Sutton PD, Ventura SJ, Menacker F, Kirmeyer S, Munson ML. Births: final data for 2005. National vital statistics reports. 2007.

3. European Commission. Study of low fertility in the regions of the European Union: places, periods and causes. Population and social conditions 32004 [cited 18.06.09];4:27-8. Available online at: http://epp.eurostat.ec.europa.eu/portal/page/ portal/product_details/publication?p_product_code=KS-CC04-005.

4. Mean age of women at childbearing [database]. European Commission. [cited 18.06.09] Available online at: http://epp. eurostat.ec.europa.eu/portal/page/portal/product_details/dataset?p_product_code=TPS00017.

5. Lappegård T. Tenåringer og fruktbarhet: sex, men ikke barn [Teenagers and fertility: Sex, but not children]. Samfunnsspeilet 2000 [cited 18.06.09];6;2-9 [in Norwegian]. Available online at: http://www.ssb.no/samfunnsspeilet/utg/200006/1. shtml.

6. Memmel LM, Miller L, Gardner J. Over-the-internet availability of hormonal contraceptives regardless of risk factors. Contraception. 2006;73(4):372-5.

7. Henshaw SK. Induced abortion: a world review, 1990. Int Fam Plan Perspect. 1990;16:59-65.

8. Births in Norway through 30 years [report]. Medical Birth Registry of Norway 1997. Available online at: http://www.fhi. no/dav/fd8abfa55c.pdf. 
9. Statistics of Norway 2009. Gjennomsnittlig fødealder, 1964-2008 [Mean age at birth, 1964-2008] [web document, cited 09.03.10, in Norwegian]. Available online at: http:// www.ssb.no/fodte/tab-2009-04-02-04.html.

10. Statistics of Norway 2009. Aldersavhengige fruktbarhetsrater og samlet fruktbarhetstall. 1961-2008 [Agedependent fertilityrates and total fertility rate. 1961-2008] [web document, cited 09.03.10. in Norwegian]. Available online at: http:// www.ssb.no/fodte/tab-2009-04-02-03.html.

11. National Institute for health and welfare. Nordic Statistics on induced abortions 2007. Statistical Report [web document] 2009; 9:[cited 09.03.10]. Available online at: http://www. stakes.fi/EN/tilastot/statisticsbytopic/reproduction/nordabortions.htm.

12. Statistics of Norway 2006. Utførte svangerskapsavbrudd, etter kvinnens alder. 1979-2005 [Termination of pregnancy, by the woman's age. 1979-2005]. [web document, cited 09.03.10, in Norwegian] Available online at: http://www.ssb.no/ emner/03/01/20/abort/tab-2006-04-26-01.html.

13. Ministry of Health and Care Services 2000. The Abortion Act [web document, cited 09.03.10]. Available online at: http://www.regjeringen.no/en/dep/hod/Documents/Veiledninger_g_brosjyrer/2000/About-the-Abortion-Act.html? id $=419252$.

14. Rapport om svangerskapsavbrudd for 2007 [Report on termination of pregnancy for 2007]. Norwegian Institue of Public health 2008 [in Norwegian]. Available online at: http://www. fhi.no/dav/956caa8168.pdf.

15. Guldi M. Fertility effects of abortion and birth control pill access for minors. Demography. 2008;45(4):817-27.

16. Foss AH. Fruktbarhet blant innvandrerkvinner: 1 av 5 nyfødte har foreldre som har innvandret [Fertility amongst immigrating women: 1 of 5 newborns have parents who has immigrated]. Samfunnsspeilet 2006 [cited 09.03.10];4;48-51 [in
Norwegian] Available online at: http://www.ssb.no/vis/samfunnsspeilet/utg/200604/07/art-2006-10-10-01.html.

17. Nesheim BI. Obstetrikk og gynekologi [Obstetrics and gynecology]. 1st edn. Gyldendal Norsk Forlag AS, Norwegian: 2004.pp.349.

18. Norwegian Institute of Public Health. Wholesaler-based drug statistics, 2009

19. Kvinners helse i Norge [Womens health in Norway]. Ministry of Health and Care Services. Norwegian: 1999. pp. 13 Available online at: http://www.regjeringen.no/nn/dep/hod/Dokument/NOU-ar/1999/nou-1999-13/9/2.html?id=352967.

20. Forebygging av uønsket svangerskap og abort blant tenåringer [Prevention of unwanted pregnancies and abortions amongst teenagers]. Health department 2006 [in Norwegian]. http:// www.regjeringen.no/nb/dep/hod/dok/rundskriv/2006/i-12006. html?id=109603.

21. Nesheim BI. Postkoital antikonsepsjon [Postcoital contraception] Tidsskr Nor Lægeforen. 2001;121:2737-8. [in Norwegian]. Available online at: http://www.tidsskriftet.no/? seks_id=399962.

22. Pedersen W, Samuelsen SO, Eksild A. Abort hos unge kvinner - betydningen av oppvekst og sosial klasse [Abortion amongst young women - the influence of childhood and social class]. Tidsskr Nor Lægeforen. 2006;126:1734-7 [in Norwegian].

23. Maher J, Macfarlane A. Trends in live births and birthweight by social class, marital status and mothers age, 1976-2000. Health Statistics Quarterly 2004;23:34-42.

24. Knudsen LB. Induced abortions in Denmark. Acta Obstet Gynecol Scand Suppl. 1997;164:54-9.

25. Skjeldestad FE, Borgan JK, Daltveit AK, Nymoen EH. Induced abortion. Effects of marital status, age and parity on choice of pregnancy termination. Acta Obstet Gynecol Scand. 1994;73(3):255-60. 